\title{
PERCEIVED IMPORTANCE AND LEVELS OF TECHNICAL ENGLISH COMMUNICATION SKILLS AMONG STAKEHOLDERS IN ENGINEERING FIELDS
}

\author{
Roger Tsz Ho Ng \\ Department of Construction Technology and Engineering \\ Technological and Higher Education Institute of \\ Hong Kong, P. R. China
}

\begin{abstract}
The purposes of this study were to examine stakeholders' perceptions of the importance of technical English communication skills in engineering and academic teachers and industry professionals' perceptions of current engineering students' and graduates' levels of technical communication skills. Survey questionnaires were designed to collect data from different research participants. The data were subsequently analysed using descriptive statistics. The study identified a discrepancy between students' self-perceived performance on technical English communication skills and their perceived standards of these skills required by the programmes in which they were enrolled. Technical communication skills, including writing in engineering genres, essays and technical reports, reading and speaking, were viewed to be fairly important for their academic success. The findings also indicated that the students' abilities in writing in engineering genres, and essays and technical report writing were perceived to be below the standards. In addition, the study highlighted that industry professionals viewed the technical communication skills of engineering graduates working in the engineering sectors as inadequate. Based on these results, it is vitally important to develop a tailor-made enhancement course to cater for the specific needs of engineering students, including technical communication skills for their study programmes and to prepare them for workplace needs of engineers in the near future.
\end{abstract}

Keywords - Engineering, Technical English Communication Skills, Genres, Performance

\section{INTRODUCTION}

English serves as an important tool for professional communication in engineering. With the advance of technology and globalization, engineering graduates must be able to communicate "across national and cultural boundaries" [1]. According to Xiao and Chen [2], "intercultural

\author{
Alex Ying Yin Wong \\ Department of Construction Technology and Engineering \\ Technological and Higher Education Institute of \\ Hong Kong, P. R. China
}

communication skills have been identified to be critical for engineering graduates, and communication has been considered as an essential skill for them to conduct international communication and cooperation". In engineering education, effective communication skills are a vital component for engineering graduates as they facilitate students to advance their future careers [3]. It is also one of the important outcomes stipulated in the requirements of undergraduate engineering programmes in the ABET Engineering Criteria 2019-2020 [4]. Such skills are vitally important "for an engineer who aspires to carry out his/her professional practice in the global arena" [3]. Hence, nurturing and developing effective communication skills is a prime action in engineering education, since it not only helps students to understand their subject materials and technical documents in English but also helps them to connect with different stakeholders in the engineering fields. Joshi [5] states that engineering graduates shall realize that "English appears even more crucial than it used to be". As future professional engineers, they must not only be equipped with the necessary professional knowledge but also to enhance their technical communication skills including writing, reading and speaking in English; in particular, these are the essential skills for engineers to communicate with "customers, subcontractors and suppliers" [6]. Engineers need to demonstrate their high calibre in oral and written communication in English [7]. According to Last, Neveu \& Smith [8], “technical communication is 'transactional' - it entails a purposeful transaction between sender and receiver that provides specific information for practical and specific purposes (informing, instructing, persuading) and is usually geared towards the needs of a specific audience".

Some studies have shown that writing is the "most prevalent activity" for professional engineers [9], since it occupies most of the working time of engineers [10] and [11]. In THEi, great emphasis has been placed on the development of work-ready graduates who develop subject knowledge and also master 
technical communication skills [12] and [13]. To meet the language needs of the study programmes, the compulsory English modules of professional writing offered by language departments aim to develop engineering students with necessary communication skills relevant to their future profession through various activities and assessments, such as job-hunting, reports, proposals, and business correspondence [14], since the English language abilities of the engineering students from different engineering programmes vary. Although the aforementioned professional English writing courses were designed to enhance engineering students' English language skills for daily business purposes, there is a great need of much more learning about technical English communication from real industry practice [15]. In addition, engineering graduates are required to pass the professional assessment (e.g. essay writing) so as to become qualified engineers. In order to equip students with necessary technical English communication skills and enable them to excel in placements and careers in the engineering sector, the curriculum development should expand from the existing core modules and provide them with additional technical English enhancement courses. Although it is known that engineering students' technical communication skills should be improved before they join the profession, it is not clear which aspects of the technical communication are needed to be enhanced.

\section{OBJECTIVES}

The objectives of this descriptive research study were to collect data on the stakeholders' perspectives of the importance of technical English communication skills, including writing, reading and speaking, in four engineering fields, the academic teachers' perspectives of the levels of technical communication skills for current engineering degree students, and the industry professionals' perspectives of the levels of technical English communication skills (e.g. engineering genres) for engineering graduates in general.

\section{METHOD}

\section{Participants}

Three different groups of respondents were involved in this study: undergraduate engineering students, academic teachers and industry professionals. The first group of respondents involved a total of 204 full-time undergraduate third and fourth-year engineering students from four different engineering fields, namely building services engineering (BSE), civil engineering (CE), environmental engineering and management (EEM), and aircraft engineering (AE). Senior students were chosen because they should start understanding the requirements of their professions, and should have gained some relevant experience when taking required professional training in the third year. The second and the third groups of respondents involved eight academic teachers from the current engineering programmes and fifteen industry professionals from the same four engineering fields (BSE, CE, EEM and $\mathrm{AE})$, respectively.

\section{Data Collection}

Three different sets of questionnaires were employed to collect data from the different groups of respondents. There were 44, 47 and 41 questions for the engineering students, academic teachers and industry professionals, respectively. The design of the questionnaire items referenced the instruments developed by [16], [17], and [18]. The content was reviewed and examined by different engineering professionals and experts in accordance with the needs of relevant industries. Each questionnaire consisted of three parts. The first part collected personal information about the students (e.g. gender and age). The academic teachers and industry professionals provided personal information such as their occupation titles. The second part of the questions were identical in the three sets of questionnaires. Three items were designed to understand different stakeholders' perspectives of the importance of the technical English communication skills (e.g. writing, reading and speaking) in different engineering fields. The remaining parts were different for the three sets of questionnaires.

The aim of parts III and IV of the student questionnaire focused on students' perspectives of the importance of technical English communication skills versus their perspectives of self-performance in technical English communication skills, in different engineering fields. An open-ended question was also provided for the studentrespondents from different engineering fields in order to give them a chance to express their issues and challenges about developing the technical English communication skills for future engineering professions. The aim of part III of both academic teachers and industry professionals' questionnaires focused on their perceptions of current students' and graduates' levels of technical communication skills, including writing, essays/technical reports, reading and speaking, in different engineering fields. The survey questionnaires were designed using a five-point Likert scale. The Cronbach's $\alpha$ of each subscale ranged between .674 and .845 and the Cronbach's $\alpha$ for the total scale was .923 , showing acceptable reliability of the student questionnaires. The research instruments received the approval of the research and ethics committee board of the tertiary institute in which the study was being conducted. The surveys were administered to the three groups of respondents. They were informed by the project officer that the questionnaires were anonymous, that their participation in the study was voluntary, and that the information they provided for this study would be kept confidential. Descriptive statistics were used to analyse the data obtained from the surveys.

\section{RESULTS}

Students' perspectives of the importance of technical English communication skills in engineering vs their own performances on technical English communication skills in different engineering programmes 


\section{International Journal of Engineering Applied Sciences and Technology, 2020 \\ Vol. 5, Issue 2, ISSN No. 2455-2143, Pages 43-50 \\ Published Online June 2020 in IJEAST (http://www.ijeast.com)}

The results presented in Table 1 show that the students, in general, perceived that technical English communication skills (i.e. writing, reading and speaking) in engineering education were fairly important, with an overall mean rating of 4.39.

Table 1 Mean and standard deviations of items on students' perspectives of the importance of technical English communication skills in different engineering programmes

\begin{tabular}{|c|c|c|c|c|c|c|c|c|c|}
\hline \multirow[b]{2}{*}{$\begin{array}{l}\text { Technical } \\
\text { communication skills* }\end{array}$} & \multicolumn{2}{|c|}{ BSE } & \multicolumn{2}{|c|}{ CE } & \multicolumn{2}{|c|}{ EEM } & \multicolumn{2}{|c|}{$\mathbf{A E}$} & \multirow[b]{2}{*}{$\begin{array}{c}\text { Overal } \\
\text { mean }\end{array}$} \\
\hline & $M$ & $S D$ & M & $S D$ & M & $S D$ & $M$ & $S D$ & \\
\hline Writing & 3.99 & 0.87 & 4.07 & 0.92 & 3.97 & 0.93 & 5.00 & 0.00 & 4.28 \\
\hline Reading & 4.03 & 0.86 & 4.38 & 0.73 & 4.14 & 0.75 & 5.00 & 0.00 & 4.39 \\
\hline Speaking & 4.12 & 0.92 & 4.64 & 0.63 & 4.30 & 0.66 & 5.00 & 0.00 & 4.51 \\
\hline Overall mean & & & & & & & & & 4.39 \\
\hline
\end{tabular}

However, when evaluating their own performances on the aforementioned skills, they were just moderately satisfied with these aspects (See Table 2). Of the three skills, they perceived their reading (mean score of 3.31) and speaking (mean score of 3.06) to be moderately satisfactory. They also perceived their writing as moderately satisfactory, but this received the lowest mean rating (overall mean 3.02). Overall they were just moderately satisfied with these three aspects (overall mean 3.31).

Table 2 Mean and standard deviations of items on students' perspectives of their own performance of technical English communication skills required in different engineering programmes

\begin{tabular}{|c|c|c|c|c|c|c|c|c|c|}
\hline \multirow[b]{2}{*}{$\begin{array}{l}\text { Technical } \\
\text { communication skills } t\end{array}$} & \multicolumn{2}{|c|}{ BSE } & \multicolumn{2}{|c|}{ CE } & \multicolumn{2}{|c|}{ EEM } & \multicolumn{2}{|c|}{$\mathbf{A E}$} & \multirow[b]{2}{*}{$\begin{array}{c}\text { Overall } \\
\text { mean }\end{array}$} \\
\hline & $M$ & $S D$ & M & $S D$ & $M$ & $S D$ & $M$ & $S D$ & \\
\hline Writing & 3.23 & 0.88 & 2.71 & 0.83 & 3.16 & 0.76 & 3.00 & 0.00 & 3.02 \\
\hline Reading & 3.40 & 0.82 & 2.92 & 0.83 & 3.43 & 0.69 & 3.50 & 0.71 & 3.31 \\
\hline Speaking & 3.25 & 0.95 & 3.00 & 1.04 & 3.00 & 0.85 & 3.00 & 0.00 & 3.06 \\
\hline Overall mean & & & & & & & & & 3.31 \\
\hline
\end{tabular}

Figure 1 provides a comparison between students' perceived importance of technical English communication skills and their own perceived performances on technical English communications in different engineering programmes

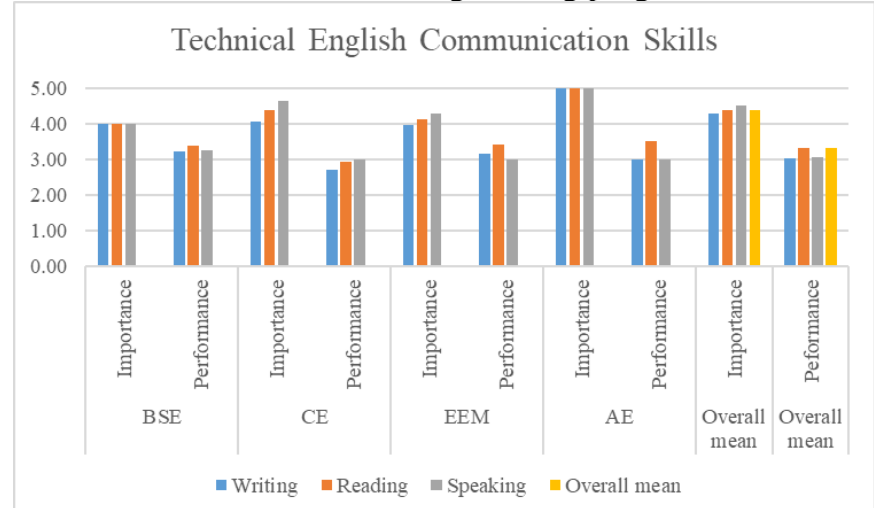

Fig 1. Perceived importance of technical English communication versus perceived performance of technical English communication
Students' perspectives of the importance of technical English communication skills (e.g. engineering genres)

From Table 3, the overall mean (4.14) suggests that technical English communication (i.e. engineering genres) perceived by the students was to be fairly important for their academic success. Speaking (overall mean $=4.26$ ) was prioritized as the most important skill, followed by reading (overall mean $=$ 4.18 ), essay \& technical write-up (overall mean $=4.16$ ) and writing engineering genres (overall mean $=3.96$ ). With regard to the engineering genres of writing, it was found that "tender specification" (mean score of 4.04), followed by "Electrical \& Mechanical (E\&M) design report" (mean score of 3.95), and "contract document" (mean score of 3.91) were perceived to be fairly important in BSE. In CE, "writing site investigation reports" and "writing contract documents" were found to be fairly important, with the highest mean score of 4.21. Similarly, "method statements", "procedures", "professional reports", "technical reports" and "tender specification" were also fairly important in CE engineering, with the mean score of 4.07. "Technical reports" (mean score of 4.24), "contract documents" (mean score of 4.08), "writing environmental impact assessment report" (mean score of 4.08), "writing environmental impact assessment reports" (mean score of 4.08), "writing environmental management plan" (mean score of 4.05), and "writing monthly Environmental Monitoring and Audit (EM\&A) report" were also fairly important in EEM. In $\mathrm{AE}$, the genres, including "writing occurrence reports" (mean score of 5.00) and "writing defect/discrepancy records" (mean score of 5.00), were considered very important.

In terms of essays/technical reports, it was found that "expressing ideas logically", "presenting discernible and satisfactory framework or pattern for text", and "writing clarity of argument" were viewed as fairly important elements in BSE, CE, EEM and AE with the mean score of 4.00 or above. Reading (e.g. operating instructions, specification, production specifications, descriptions, technical manuals and interpreting graphs, charts and tables, etc.) was also viewed to be fairly important in BSE, CE, EEM and AE with the mean score of 4.00 or above.

In terms of speaking, "conveying messages/delivering information while speaking", explaining technical faults to senior management", "presenting oral reports/doing presentations to clients" and "speaking to different parties and operating instructions" were perceived as fairly important by the respondents from $\mathrm{BSE}, \mathrm{CE}, \mathrm{EEM}$, and $\mathrm{AE}$ with the mean score of 4.00 or above.

Table 3 Importance of technical English communication skills (e.g. engineering genres) in different engineering fields 


\begin{tabular}{|c|c|c|c|c|c|}
\hline Items* & $\begin{array}{c}\text { BSE } \\
\text { Mean }\end{array}$ & $\begin{array}{c}\text { CE } \\
\text { Mean }\end{array}$ & $\begin{array}{l}\text { EEM } \\
\text { Mean }\end{array}$ & $\begin{array}{c}\text { AE } \\
\text { Mean }\end{array}$ & $\begin{array}{c}\text { Overall } \\
\text { mean }\end{array}$ \\
\hline \multicolumn{6}{|l|}{ Writing engineering genres } \\
\hline Building trade specific vocabulary - Technical & 3.81 & $\mathrm{n} / \mathrm{a}$ & 3.76 & $\mathrm{n} / \mathrm{a}$ & \\
\hline Operation and maintenance manual & 3.84 & $\mathrm{n} / \mathrm{a}$ & $\mathrm{n} / \mathrm{a}$ & $\mathrm{n} / \mathrm{a}$ & \\
\hline Writing environmental impact assessment report & $\mathrm{n} / \mathrm{a}$ & 3.71 & 4.08 & $\mathrm{n} / \mathrm{a}$ & \\
\hline $\begin{array}{l}\text { Writing professional/technical reports (e.g. format, } \\
\text { style \& expressions, etc.) }\end{array}$ & $\mathrm{n} / \mathrm{a}$ & 4.07 & 4.24 & $\mathrm{n} / \mathrm{a}$ & \\
\hline Transcoding (e.g. graphs, charts, tables, etc.) & 3.74 & 3.36 & 3.78 & $\mathrm{n} / \mathrm{a}$ & \\
\hline Writing E\&M design report & 3.95 & $\mathrm{n} / \mathrm{a}$ & $\mathrm{n} / \mathrm{a}$ & $\mathrm{n} / \mathrm{a}$ & \\
\hline Writing method statements/procedures & $\mathrm{n} / \mathrm{a}$ & 4.07 & 3.92 & $\mathrm{n} / \mathrm{a}$ & \\
\hline Writing contract document & 3.91 & 4.21 & 4.08 & 3.50 & \\
\hline Writing literature review & 3.70 & 3.50 & 3.95 & 4.00 & \\
\hline Writing logbook/daily record worksheet & 3.72 & 3.86 & 3.84 & 4.50 & \\
\hline Writing memos & 3.48 & 3.21 & 3.54 & $\mathrm{n} / \mathrm{a}$ & \\
\hline Writing minutes & 3.62 & 3.21 & 3.68 & $\mathrm{n} / \mathrm{a}$ & \\
\hline Writing site investigation report & 3.89 & 4.21 & 4.00 & 4.50 & 3.96 \\
\hline Writing tender specification & 4.04 & 4.07 & 3.95 & 3.50 & \\
\hline Writing EMS manual & $\mathrm{n} / \mathrm{a}$ & $\mathrm{n} / \mathrm{a}$ & 4.00 & $\mathrm{n} / \mathrm{a}$ & \\
\hline Writing environmental management plan & $\mathrm{n} / \mathrm{a}$ & $\mathrm{n} / \mathrm{a}$ & 4.05 & $\mathrm{n} / \mathrm{a}$ & \\
\hline Writing monthly EM\&A report & $\mathrm{n} / \mathrm{a}$ & $\mathrm{n} / \mathrm{a}$ & 4.05 & $\mathrm{n} / \mathrm{a}$ & \\
\hline Writing guideline for environment & $\mathrm{n} / \mathrm{a}$ & $\mathrm{n} / \mathrm{a}$ & 4.03 & $\mathrm{n} / \mathrm{a}$ & \\
\hline Writing reports on equipment condition & $\mathrm{n} / \mathrm{a}$ & $\mathrm{n} / \mathrm{a}$ & 3.97 & $\mathrm{n} / \mathrm{a}$ & \\
\hline Writing syntax and use of appropriate cohesive devices & $\mathrm{n} / \mathrm{a}$ & $\mathrm{n} / \mathrm{a}$ & 3.95 & $\mathrm{n} / \mathrm{a}$ & \\
\hline Writing audit report & $\mathrm{n} / \mathrm{a}$ & $\mathrm{n} / \mathrm{a}$ & $\mathrm{n} / \mathrm{a}$ & 4.50 & \\
\hline Writing formal letter & $\mathrm{n} / \mathrm{a}$ & $\mathrm{n} / \mathrm{a}$ & $\mathrm{n} / \mathrm{a}$ & 4.00 & \\
\hline Writing company procedure manual & $\mathrm{n} / \mathrm{a}$ & $\mathrm{n} / \mathrm{a}$ & $\mathrm{n} / \mathrm{a}$ & 4.50 & \\
\hline Writing rectification instruction & $\mathrm{n} / \mathrm{a}$ & $\mathrm{n} / \mathrm{a}$ & $\mathrm{n} / \mathrm{a}$ & 4.50 & \\
\hline Writing occurrence report & $\mathrm{n} / \mathrm{a}$ & $\mathrm{n} / \mathrm{a}$ & $\mathrm{n} / \mathrm{a}$ & 5.00 & \\
\hline $\begin{array}{l}\text { Writing defect/discrepancy records } \\
\text { Essay/technical write up for } \mathbf{H K I E}^{1}\end{array}$ & $\mathrm{n} / \mathrm{a}$ & $\mathrm{n} / \mathrm{a}$ & $\mathrm{n} / \mathrm{a}$ & 5.00 & \\
\hline Avoiding jargon, catchphrases, undefined abbreviations & 3.79 & 4.08 & 3.89 & 4.50 & \\
\hline Expressing ideas logically & 3.92 & 4.21 & 4.30 & 4.50 & \\
\hline $\begin{array}{l}\text { Presenting discernible and satisfactory framework or } \\
\text { pattern for text }\end{array}$ & 3.85 & 4.07 & 4.19 & 4.50 & 4.16 \\
\hline Spelling and punctuation & 3.62 & 3.69 & 4.00 & 4.50 & \\
\hline Writing clarity of argument & 3.81 & 4.14 & 4.35 & 5.00 & \\
\hline Writing concise and grammatically correct & 3.73 & 3.93 & 4.24 & 4.50 & \\
\hline \multicolumn{6}{|l|}{ Reading } \\
\hline Interpreting graphs, charts, tables, etc. & 3.82 & 3.71 & 4.14 & 4.00 & \\
\hline Reading machine parameters/data & 3.79 & 4.00 & 3.97 & 5.00 & \\
\hline Reading manuals / technical manuals (AMM/IPC/GMM) & 3.78 & 4.00 & 4.27 & 5.00 & 4.18 \\
\hline Reading operating instructions/specifications & 3.85 & 4.07 & 4.24 & 5.00 & \\
\hline Reading production specifications/descriptions & 3.85 & 4.14 & 4.05 & 5.00 & \\
\hline
\end{tabular}

\begin{tabular}{|c|c|c|c|c|c|}
\hline Conveying messages/delivering information while speaking & 3.95 & 4.14 & 4.19 & 5.00 & \multirow{8}{*}{4.26} \\
\hline Discussing how to tackle work-related issues & 3.91 & 4.14 & 4.32 & 5.00 & \\
\hline Explaining technical faults to senior management & 3.99 & 4.36 & 4.11 & 5.00 & \\
\hline Fluency/accuracy in speaking & 3.91 & 4.36 & 4.25 & 4.00 & \\
\hline Presenting oral reports/doing presentations to clients & 4.06 & 4.36 & 4.31 & 5.00 & \\
\hline Speaking in seminars/conferences & 3.84 & 4.07 & 4.08 & 5.00 & \\
\hline Speaking to different parties about operating instructions & 3.84 & 4.36 & 4.11 & 5.00 & \\
\hline Using non-academic vocabulary/jargon in public speaking & 3.81 & 3.93 & 4.03 & 4.00 & \\
\hline Overall mean & & & & & 4.14 \\
\hline
\end{tabular}

Academic teachers' perspectives of the importance of technical English communication skills in engineering fields
The academic teachers in BSE, CE, EEM and AE also perceived that technical communication skills were very fairly important, with the overall mean rating of 4.60. Writing (overall mean $=4.80$ ), followed by reading \& speaking (overall mean $=4.50$ ) were perceived to be fairly important for academic success (See Table 4).

Table 4 Means and standard deviations of items on academic teachers' perceived importance of technical English communication skills in the four engineering professions

\begin{tabular}{|c|c|c|c|c|c|c|c|c|c|}
\hline & \multicolumn{2}{|c|}{ BSE } & \multicolumn{2}{|c|}{ CE } & \multicolumn{2}{|c|}{ EEM } & \multicolumn{2}{|c|}{$\mathbf{A E}$} & \multirow[b]{2}{*}{$\begin{array}{c}\text { Overall } \\
\text { mean }\end{array}$} \\
\hline $\begin{array}{l}\text { Technical } \\
\text { communication skills* }\end{array}$ & M & $S D$ & $M$ & $S D$ & $M$ & $S D$ & $M$ & $S D$ & \\
\hline Writing & 5.00 & 0.88 & 5.00 & 0.83 & 4.00 & 0.76 & 5.00 & 0.00 & 4.80 \\
\hline Reading & 5.00 & 0.82 & 4.00 & 0.83 & 4.00 & 0.69 & 5.00 & 0.71 & 4.50 \\
\hline Speaking & 5.00 & 0.95 & 4.00 & 1.04 & 4.00 & 0.85 & 5.00 & 0.00 & 4.50 \\
\hline Overall mean & & & & & & & & & 460 \\
\hline
\end{tabular}

Academic teachers' perspectives of the levels of technical English communication skills for current engineering students

Table 5 shows the responses concerning the teachers' perceptions of current engineering students' skills. The overall mean of 2.82 implies that they perceived students' capability in technical English communication skills to be below standard. With regard to the engineering genres, the respondents from BSE regarded the students' technical English writing, other than "building trade specific vocabulary - technical" (mean score of 3.0) and "transcoding" (mean score of 3.0), not to have met the standards. Similarly, the respondents from $\mathrm{CE}$ regarded the students' technical writing, other than "transcoding" (mean score of 3.5) and "logbook" (mean score of 3.5), as not having met the standards. For EEM, the respondents considered that the students' levels of technical English communication skills in "building trade specific vocabulary" (mean score of 3.00), and "transcoding" (mean score of 3.00) met the standards. However, writing in engineering genres such as "Environmental Management System (EMS) manuals" (mean score of 2.50), "memos" (mean score of 2.50), "EM\&A reports" (mean score of 2.50), "contract documents" (mean score of 2.00), "logbooks" (mean score of 2.00) and "professional/technical reports" (mean score of 2.00), either failed to meet standards or was below standard. The respondents from AE regarded the students' levels of technical English communication skills in "contract documents" (mean score of 3.50), "tender specifications" (mean score of 3.50), "operational and maintenance manual" (mean score of 3.00), "rectification instructions" (mean score of 3.00), "audit reports" (mean score of 3.00) and "literature reviews" (mean score of 3.00) just met the standards. Writing in other engineering genres were rated as failing to meet standards.

In terms of essay/technical write up, all respondents from BSE, CE, EEM and AE regarded their students' performance as meeting the standards, except for writing genres such as 
"writing clarity of arguments" and "writing concisely and grammatically correctly", were rated as below standard by the teachers from BSE, CE and EEM. For reading, respondents from both $\mathrm{CE}$ and $\mathrm{AE}$ regarded their students' capabilities in "interpreting graphs, charts, tables" (mean score of 3.50), "reading machine parameters/data" (mean score of 3.50), "reading manuals" (mean score of 3.50), and "reading operating instruction/specifications" (mean score of 3.50) as above standard. Other were areas rated as meeting standards. Last, the teacher-respondents from all four engineering professions regarded their students' oral and presentation skills either as just meeting or below standard.

Table - 5 Perceived levels of technical English communication skills for current engineering students

\begin{tabular}{|c|c|c|c|c|c|}
\hline Items\# & $\begin{array}{c}\text { BSE } \\
\text { Mean }\end{array}$ & $\begin{array}{c}\text { CE } \\
\text { Mean }\end{array}$ & $\begin{array}{l}\text { EEM } \\
\text { Mean }\end{array}$ & $\begin{array}{c}\mathrm{AE} \\
\text { Mean }\end{array}$ & $\begin{array}{c}\text { Overall } \\
\text { mean }\end{array}$ \\
\hline \multicolumn{6}{|l|}{ Writing engineering genres } \\
\hline Building trade specific vocabulary - Technical & 3.00 & $\mathrm{n} / \mathrm{a}$ & 3.00 & $\mathrm{n} / \mathrm{a}$ & \\
\hline Operation and maintenance manual & 2.00 & $\mathrm{n} / \mathrm{a}$ & $n / a$ & $n / a$ & \\
\hline Transcoding (e.g. graphs, charts, tables, etc.) & 3.00 & 3.50 & 3.00 & n/a & \\
\hline Writing audit report & $n / a$ & $\mathrm{n} / \mathrm{a}$ & $\mathrm{n} / \mathrm{a}$ & 3.00 & \\
\hline Writing company procedure manual & $\mathrm{n} / \mathrm{a}$ & $\mathrm{n} / \mathrm{a}$ & $\mathrm{n} / \mathrm{a}$ & 3.00 & \\
\hline Writing contract document & 2.00 & 2.50 & 2.00 & 3.50 & \\
\hline Writing defect/discrepancy records & $n / a$ & $\mathrm{n} / \mathrm{a}$ & $\mathrm{n} / \mathrm{a}$ & 2.50 & \\
\hline Writing E\&M design report & 2.00 & $\mathrm{n} / \mathrm{a}$ & $\mathrm{n} / \mathrm{a}$ & n/a & \\
\hline Writing EMS manual & $n / a$ & $\mathrm{n} / \mathrm{a}$ & 2.50 & n/a & \\
\hline Writing environmental impact assessment report & $n / a$ & 2.50 & 3.00 & $\mathrm{n} / \mathrm{a}$ & \\
\hline Writing environmental management plan & $\mathrm{n} / \mathrm{a}$ & $\mathrm{n} / \mathrm{a}$ & 3.00 & $\mathrm{n} / \mathrm{a}$ & \\
\hline Writing formal letter & $n / a$ & $\mathrm{n} / \mathrm{a}$ & $\mathrm{n} / \mathrm{a}$ & 2.50 & \\
\hline Writing guideline for environment & $n / a$ & $\mathrm{n} / \mathrm{a}$ & 3.00 & $n / a$ & \\
\hline Writing literature reviews & 2.00 & 2.50 & 3.00 & 3.00 & 2.58 \\
\hline Writing logbook/daily record worksheet & 2.00 & 3.50 & 2.00 & 2.50 & \\
\hline Writing memos & 2.00 & 2.50 & 2.50 & $\mathrm{n} / \mathrm{a}$ & \\
\hline Writing method statements/procedures & $\mathrm{n} / \mathrm{a}$ & 2.50 & 3.00 & $\mathrm{n} / \mathrm{a}$ & \\
\hline Writing minutes & 2.00 & 2.00 & 2.00 & $n / a$ & \\
\hline Writing monthly EM\&A report & $\mathrm{n} / \mathrm{a}$ & $\mathrm{n} / \mathrm{a}$ & 2.50 & $\mathrm{n} / \mathrm{a}$ & \\
\hline Writing occurrence report & $\mathrm{n} / \mathrm{a}$ & $\mathrm{n} / \mathrm{a}$ & $\mathrm{n} / \mathrm{a}$ & 2.50 & \\
\hline $\begin{array}{l}\text { Writing professional/technical reports (e.g. format, style \& } \\
\text { expressions, etc.) }\end{array}$ & $\mathrm{n} / \mathrm{a}$ & 2.50 & 2.00 & $\mathrm{n} / \mathrm{a}$ & \\
\hline Writing rectification instruction & $\mathrm{n} / \mathrm{a}$ & $\mathrm{n} / \mathrm{a}$ & $\mathrm{n} / \mathrm{a}$ & 3.00 & \\
\hline Writing reports on equipment condition & $n / a$ & $\mathrm{n} / \mathrm{a}$ & 3.00 & $\mathrm{n} / \mathrm{a}$ & \\
\hline Writing site investigation report & 2.00 & 2.50 & 3.00 & 2.50 & \\
\hline Writing syntax and use of appropriate cohesive devices & $n / a$ & $\mathrm{n} / \mathrm{a}$ & 2.50 & $n / a$ & \\
\hline Writing tender specification & 2.00 & 2.50 & 2.50 & 3.50 & \\
\hline \multicolumn{6}{|l|}{ Essay/technical write-up for HKIE } \\
\hline Avoiding jargon, catchphrases, undefined abbreviations & 3.00 & 3.00 & 3.00 & 2.50 & \multirow{6}{*}{2.63} \\
\hline Expressing ideas logically & 3.00 & 3.50 & 2.50 & 3.00 & \\
\hline $\begin{array}{l}\text { Presenting discernible and satisfactory framework or } \\
\text { pattern for text }\end{array}$ & 3.00 & 3.00 & 3.00 & 2.50 & \\
\hline Spelling and punctuation & 2.00 & 3.00 & 3.50 & 3.00 & \\
\hline Writing clarity of argument & 2.00 & 2.50 & 2.50 & 3.00 & \\
\hline Writing concise and grammatically correct & 2.00 & 2.50 & 2.00 & 3.00 & \\
\hline \multicolumn{6}{|l|}{ Reading } \\
\hline Interpreting graphs, charts, tables, etc. & 3.00 & 3.50 & 3.00 & 3.50 & \multirow{5}{*}{3.28} \\
\hline Reading machine parameters/data & 3.00 & 4.00 & 3.00 & 3.50 & \\
\hline Reading manuals & 3.00 & 3.50 & 3.00 & 3.50 & \\
\hline Reading operating instructions/specifications & 3.00 & 3.50 & 3.00 & 3.50 & \\
\hline Reading production specifications/descriptions & 3.00 & 3.50 & 3.00 & 3.50 & \\
\hline \multicolumn{6}{|l|}{ Speaking } \\
\hline Conveying messages/delivery information while speaking & 3.00 & 3.50 & 3.00 & 3.00 & \multirow{8}{*}{2.80} \\
\hline Discussing how to tackle work-related issues & 3.00 & 3.50 & 3.00 & 3.00 & \\
\hline Explaining technical faults to senior management & 2.00 & 3.00 & 3.00 & 3.00 & \\
\hline Fluency/accuracy in speaking & 2.00 & 2.50 & 2.50 & 3.00 & \\
\hline Presenting oral reports/doing presentations to clients & 3.00 & 2.50 & 2.50 & 2.50 & \\
\hline Speaking in seminars/conferences & 3.00 & 2.00 & 2.50 & 3.00 & \\
\hline Speaking to clients about operating instructions & 3.00 & 2.50 & 2.50 & 2.50 & \\
\hline Using non-academic vocabulary/jargon in public speaking & 3.00 & 3.00 & 2.50 & 3.50 & \\
\hline Overall mean & & & & & 2.82 \\
\hline
\end{tabular}

Industry professionals' perspectives of the importance of technical English communication skills in engineering fields

The industry professionals in BSE, CE, EEM and AE viewed technical writing as fairly important, with an overall mean rating of 4.23. Writing (mean score of 4.70), reading (mean score of 4.33) and speaking (mean score of 3.65) were also perceived as fairly important skills (See Table 6).

Table - 6 Means and standard deviations of items on industry professionals' perceived importance of technical English communication skills in the four engineering professions

\begin{tabular}{|c|c|c|c|c|c|c|c|c|c|}
\hline \multirow[b]{2}{*}{$\begin{array}{l}\text { Technical } \\
\text { communication skills* }\end{array}$} & \multicolumn{2}{|c|}{ BSE } & \multicolumn{2}{|c|}{ CE } & \multicolumn{2}{|c|}{ EEM } & \multicolumn{2}{|c|}{$\mathbf{A E}$} & \multirow[b]{2}{*}{$\begin{array}{c}\text { Overall } \\
\text { mean }\end{array}$} \\
\hline & M & $S D$ & $M$ & $S D$ & M & $S D$ & $M$ & $S D$ & \\
\hline Writing & 5.00 & 0.88 & 4.50 & 0.83 & 4.78 & 0.76 & 4.50 & 0.00 & 4.70 \\
\hline Reading & 5.00 & 0.82 & 3.50 & 0.83 & 4.33 & 0.69 & 4.50 & 0.71 & 4.33 \\
\hline Speaking & 4.00 & 0.95 & 3.00 & 1.04 & 4.11 & 0.85 & 3.00 & 0.00 & 3.65 \\
\hline Overall mean & & & & & & & & & 4.23 \\
\hline
\end{tabular}

Industry professionals' perspectives of the levels of technical English communication skills for current graduates in BSE, $C E$, EEM and $A E$

Table 6 presents the industry professionals' responses regarding the perceived levels of the skills of recent graduates. It was found that the respondents from BSE viewed students' ability in technical English writing as meeting the standard. "Writing contract documents" was perceived as below standard with the mean score of 2.50. The respondents from CE regarded the students' technical writing, other than "transcoding" (mean score of 4.00), "writing environmental impact assessment report" (mean score of 3.50) and "writing logbook/daily record worksheet" (mean score of 3.50), as having met the standards. Other engineering genres such as "method statements/procedures" (mean score of 2.50), "minutes" (mean score of 2.50), "contract documents" (mean score of 2.00) and "tender specifications" (mean score of 2.00) were found to be below standard. The respondents from EEM regarded the students' levels of technical English communication skills in "writing logbooks/daily record worksheets", "writing site investigation reports" met the standards, with a mean of 3.67. Other engineering genres were also rated as meeting the standards, except for "writing tender specification" and "writing contract document", with the mean scores of 2.78 and 2.56, respectively, which mean they were seen as below standard. In addition, the respondents from AE thought the students' writing skills in 'logbook/daily record worksheet" (mean score of 3.00), "rectification instruction" (mean score of 3.00) and "formal letter" (mean score of 3.00) met the standards. Other engineering genres (e.g. contract document, company procedure manual, occurrence report, defect/discrepancy records, investigation report, audit report and tender specification, etc.) were perceived as below the standards. All respondents from CE regarded their students' reading skills (e.g. interpreting graphs, charts and tables, etc., and reading production specifications/descriptions) were 
above the standards with mean score of 4.0. In general, reading skills (mean score of 3.50 or above) were perceived as meeting the standards in BSE, EEM and AE. Other oral communication skills (e.g. explaining technical faults to senior management, fluency/accuracy in speaking, presenting oral reports/doing presentations to clients, speaking in seminars/conferences and using non-academic vocabulary/jargon in public speaking) were perceived as below standard.

Table - 7 Perceived levels of technical English communication skills for engineering graduates

\begin{tabular}{|c|c|c|c|c|c|}
\hline Items\# & $\begin{array}{c}\text { BSE } \\
\text { Mean }\end{array}$ & $\begin{array}{c}\mathrm{CE} \\
\text { Mean }\end{array}$ & $\begin{array}{l}\text { EEM } \\
\text { Mean }\end{array}$ & $\begin{array}{c}\mathrm{AE} \\
\text { Mean }\end{array}$ & $\begin{array}{c}\text { Overall } \\
\text { mean }\end{array}$ \\
\hline \multicolumn{6}{|l|}{ Writing engineering genres } \\
\hline Building trade specific vocabulary - Technical & 3.00 & $\mathrm{n} / \mathrm{a}$ & 3.11 & $\mathrm{n} / \mathrm{a}$ & \multirow{25}{*}{2.90} \\
\hline Operation and maintenance manual & 3.00 & n/a & $\mathrm{n} / \mathrm{a}$ & $\mathrm{n} / \mathrm{a}$ & \\
\hline Transcoding (e.g. graphs, charts, tables, etc.) & 3.00 & 4.00 & 3.33 & $\mathrm{n} / \mathrm{a}$ & \\
\hline Writing audit report & $\mathrm{n} / \mathrm{a}$ & $\mathrm{n} / \mathrm{a}$ & $\mathrm{n} / \mathrm{a}$ & 2.00 & \\
\hline Writing company procedure manual & $\mathrm{n} / \mathrm{a}$ & n/a & $\mathrm{n} / \mathrm{a}$ & 2.50 & \\
\hline Writing contract document & 2.50 & 2.00 & 2.56 & 2.50 & \\
\hline Writing defect/discrepancy records & $\mathrm{n} / \mathrm{a}$ & n/a & $\mathrm{n} / \mathrm{a}$ & 2.50 & \\
\hline Writing E\&M design report & 3.00 & n/a & 3.22 & n/a & \\
\hline Writing EMS manual & $\mathrm{n} / \mathrm{a}$ & n/a & 3.22 & n/a & \\
\hline Writing environmental impact assessment report & $\mathrm{n} / \mathrm{a}$ & 3.50 & 3.22 & $\mathrm{n} / \mathrm{a}$ & \\
\hline Writing environmental management plan & $\mathrm{n} / \mathrm{a}$ & n/a & 3.11 & $\mathrm{n} / \mathrm{a}$ & \\
\hline Writing formal letter & $\mathrm{n} / \mathrm{a}$ & $\mathrm{n} / \mathrm{a}$ & $\mathrm{n} / \mathrm{a}$ & 3.00 & \\
\hline Writing guideline for environment & $\mathrm{n} / \mathrm{a}$ & $\mathrm{n} / \mathrm{a}$ & 3.22 & $\mathrm{n} / \mathrm{a}$ & \\
\hline Writing literature reviews & $\mathrm{n} / \mathrm{a}$ & $n / a$ & $n / a$ & 2.00 & \\
\hline Writing logbook/daily record worksheet & 3.00 & 3.50 & 3.67 & 3.00 & \\
\hline Writing memos & 3.50 & 3.00 & 3.22 & $\mathrm{n} / \mathrm{a}$ & \\
\hline Writing method statements/procedures & $n / a$ & 2.50 & 3.22 & $\mathrm{n} / \mathrm{a}$ & \\
\hline Writing minutes & 3.50 & 2.50 & 3.00 & n/a & \\
\hline Writing occurrence report & $\mathrm{n} / \mathrm{a}$ & $\mathrm{n} / \mathrm{a}$ & $\mathrm{n} / \mathrm{a}$ & 2.50 & \\
\hline $\begin{array}{l}\text { Writing professional/technical reports (e.g. format, style } \\
\text { \& expressions, etc.) }\end{array}$ & $n / a$ & 3.00 & 3.00 & $\mathrm{n} / \mathrm{a}$ & \\
\hline Writing rectification instruction & $\mathrm{n} / \mathrm{a}$ & $\mathrm{n} / \mathrm{a}$ & $n / a$ & 3.00 & \\
\hline Writing reports on equipment condition & $\mathrm{n} / \mathrm{a}$ & n/a & 3.00 & $\mathrm{n} / \mathrm{a}$ & \\
\hline Writing site investigation report & 3.00 & 3.00 & 3.67 & 2.50 & \\
\hline Writing syntax and use of appropriate cohesive devices & $\mathrm{n} / \mathrm{a}$ & $\mathrm{n} / \mathrm{a}$ & 3.33 & $\mathrm{n} / \mathrm{a}$ & \\
\hline Writing tender specification & 3.00 & 2.00 & 2.78 & 2.00 & \\
\hline \multicolumn{6}{|l|}{ Reading } \\
\hline Interpreting graphs, charts, tables, etc. & 3.50 & 4.00 & 3.56 & 3.50 & \multirow{6}{*}{3.38} \\
\hline Reading machine parameters/data & 3.00 & 3.00 & 3.33 & 4.00 & \\
\hline Reading manuals & 3.00 & 3.50 & 3.33 & 3.00 & \\
\hline Reading operating instructions/specifications & 3.00 & 3.00 & 3.44 & 3.00 & \\
\hline Reading production specifications/descriptions & 3.50 & 4.00 & 3.44 & 3.50 & \\
\hline \multicolumn{5}{|l|}{ Speaking } & \\
\hline Conveying messages/delivery information while & 2.50 & 3.00 & 3.11 & 3.50 & \multirow{8}{*}{2.71} \\
\hline $\begin{array}{l}\text { speakung } \\
\text { Discussing how to tackle work-related issues }\end{array}$ & 3.00 & 2.50 & 3.00 & 2.50 & \\
\hline Explaining technical faults to senior management & 2.50 & 2.50 & 3.11 & 3.00 & \\
\hline Fluency/accuracy in speaking & 3.00 & 2.00 & 2.78 & 2.50 & \\
\hline Presenting oral reports/doing presentations to clients & 2.50 & 2.50 & 3.00 & 3.00 & \\
\hline Speaking in seminars/conferences & 3.00 & 2.00 & 2.56 & 2.50 & \\
\hline Speaking to clients about operating instructions & 2.50 & 3.00 & 3.00 & 2.00 & \\
\hline $\begin{array}{l}\text { Using non-academic vocabulary/jargon in public } \\
\text { speaking }\end{array}$ & 3.00 & 2.50 & 2.67 & 2.50 & \\
\hline Overall mean & & & & & 3.05 \\
\hline
\end{tabular}

Notef: Likert Scale: $5=$ Far above standards;
1=Far below standard; Not applicable (n/a)

\section{DISCUSSION AND CONCLUSION}

The aim of this study was to understand different stakeholders' perceptions of the importance of technical
English communication skills in engineering, as well as academic teachers' and industry professionals' perceptions of current engineering students' and graduates' levels of technical communication skills. A survey questionnaire was completed as it provided fruitful information about their perceived needs and importance of technical English communication in different engineering fields. First, the study findings of this study indicate that there was a discrepancy between students' self-perceived performance on technical English communication skills and their perceived standards of these skills required by their programmes in which they were enrolled. Current engineering students are likely to experience technical communication issues in several aspects of all three categories of writing, reading and speaking.

Second, with regard to importance of technical communication skills in engineering, most student respondents from $\mathrm{BSE}, \mathrm{CE}, \mathrm{EEM}$ and $\mathrm{AE}$ realized the importance of technical English skills, in particular for engineering genres such "method statements", "professional/technical/assessment/site investigation reports", "tender specifications", "contract documents and/or occurrence reports". This finding is consistent with previous researchers' results: writing skills were rated by engineers to be extremely important for career advancement [18]. Professional writing skills, including "expressing ideas logically", "presenting discernible and satisfactory framework or pattern for text", and "writing clarity of argument" were perceived as fairly important elements for them. "Oral presentation to clients" and "explaining technical faults to senior management" emerged as the two main causes for concern, thus the academic teachers should consider training engineering students in these areas.

Third, the common point of view of different academic staff in $\mathrm{BSE}, \mathrm{CE}, \mathrm{EEM}$ and $\mathrm{AE}$ was that they regarded technical English communication skills in all three areas of writing, speaking and listening as very important in engineering professions. When asked how they perceived current engineering students' levels of technical English communication skills, the majority of the respondents from $\mathrm{BSE}, \mathrm{CE}$, and EEM, indicated that most of the students either met the standards for some aspects of writing in engineering genres (e.g. transcoding, writing log book) or were below standard for others (e.g. contract documents, site investigation reports, tender specifications). The exception was AE, in which "writing contract documents" and "tender specifications" were perceived as meeting the standards. Other genres, such as "writing clarity of argument" and "writing concise and grammatically correct", were rated as below standard by the respondents from BSE, CE and EEM.

Fourth, the BSE, AE, CE and AE engineers' point of view was that technical English writing, reading and speaking are fairly important in engineering areas. This finding is also in line with the previous researchers' results: over $70 \%$ of engineers rated the quality of their writing as either "very important" or 


\section{International Journal of Engineering Applied Sciences and Technology, 2020 \\ Vol. 5, Issue 2, ISSN No. 2455-2143, Pages 43-50 \\ Published Online June 2020 in IJEAST (http://www.ijeast.com)}

"extremely important" to the performance of their jobs (p. 4) [19]. Similarly, when asked how they viewed recent engineering graduates' levels of technical English communication skills, the respondents from $\mathrm{CE}$ regarded writing performance on engineering genres such as "method statements/procedures", "minutes", "contract documents" and "tender specifications" as below standard. "Writing tender specifications" and "writing contract documents" were also perceived as below standard by the BSE, EEM and AE respondents. Oral communication skills appeared to be the weakest skills that need to be addressed more in engineering courses.

All in all, this study provides valuable information to the course designer and academic teachers in terms of the significance of technical communication skills and has highlighted the importance of enhanced course(s), in particular catering for the needs of engineering students in terms of their technical communication skills, not only to facilitate them to develop the competencies required for their studies, but also to prepare them for the workplace needs of engineers in near future.

\section{REFERENCES}

[1] Moulton, D., Corcoran, P., James, P., \& Rathore, P. (2017). A community of practice for blended science and engineering learning and teaching at UniSA. In McDonald, J. \& Cater-Steel, A. (Eds.), Implementing communities of practice in higher education: dreamers and Schemers (p. 259). Springer Nature Singapore.

[2] Chen, X., \& Xiao, G. (2015). English academic writing difficulties of engineering students at the tertiary level in China. World Transactions on Engineering and Technology Education, 13(3), (pp.259-263).

[3] Riemer, M. J. (2007). Communication skills for the $21^{\text {st }}$ century engineer. Global J. of Eng. Educ., 11(1), (pp.89100).

[4] Criteria for Accrediting Engineering Programs, 20192020. Retrieved on $15^{\text {th }}$ June, 2020 from https://www.abet.org/accreditation/accreditationcriteria/criteria-for-accrediting-engineering-programs2019-2020/

[5] Joshi, D. H. (2013). Importance of English language for students of engineering, Gurjart, India: VSRD International Journal of Technical \& Non-Technical Research, 4(3), (pp. 50-56).

[6] Changpueng, P., \& Pattanapichet, F. (2015). An analysis of English in the workplace: The needs of engineers in writing in English. Silpakorn University Journal of Social Sciences, Humanities, and Arts, 15(3), (pp. 151-176).
[7] Shrestha, R. N., Pahari, B. R., \& Awasthi, J. R. (2016). Importance of English in engineering for professional communication: A study in the Nepalese context. Journal of the Institute of Engineering, 12(1), (pp. 222-227).

[8] Last, S., Neveu, C., \& Smith, M. (2019). Technical writing essentials: Introduction to professional communications in the technical fields. University of Victoria, Victoria, British Columbia, Canada, (pp. 1-269).

[9] Cunningham, D. \& Stewart, J. (2012). Perceptions and practices: A survey of professional engineers and architects. International Scholarly Research Network ISRN Education, (pp. 1-10). Doi:10.5402/2012/617137

[10] Silyn-Rebert, H. (1998). Using engineers' characteristics to improve reporting writing instruction. Journal of Professional Issues in Engineering Education and Practice, 24, (pp.12-16).

[11] Sageev, P., \& Romanowski, C. (2001). A message from recent engineering graduates in the workplace: Results of a survey on technical communication skills. Journal of Engineer Education, 90(4), (pp.685-742).

[12] Vocational Training Council (VTC) (2019). Strategic Plan. Retrieved from http://www.vtc.edu.hk/html/en/about/strategic plan.html

[13] Technological and Higher Education Institute of Hong Kong (THEi) (2019). Our Approach. Retrieved from http://www.thei.edu.hk/about-thei/our-approach

[14] Technological and Higher Education Institute of Hong Kong (THEi) (2019). Core Modules - English. Retrieved on $19^{\text {th }}$ June, 2020 from http://www.thei.edu.hk/facultiesand-department/general-education-andlanguages/modules-information/core-modules-english/

[15] Othlhomile, T. S., \& Mokgwathi, B. E. (2015). Technical writing as an important component of engineering education: A case study. BIE Journal of Engineering and Applied Sciences, 6(1), (pp.61-68).

[16] Canbay M. O. (2006). Strengthening a content-based instruction curriculum by a need analysis. (Unpublished master's thesis), Bilkent University, Ankara, Turkey, (pp.65-73).

[17] Şahana, Ö., Çobanb, M., \& Topkayac, T. E. (n.d.). A language needs analysis of engineering undergraduate students at a technical university: A multidimensional approach, (pp. 17-21). Retrieved on $15^{\text {th }}$ June, 2020 from http://depo.btu.edu.tr/dosyalar/bidb/Dosyalar/A\%20Lang uage $\% 20$ Needs $\% 20$ Analysis $\% 20$ of $\% 20$ Engineering $\% 20$ 
Undergraduate $\% 20$ Students $\% 20$ at $\% 20 \mathrm{a} \% 20 \mathrm{Technical} \% 2$

0University.pdf

[18] Tinh, Le Cao. (2015). Needs analysis of English for mechanical engineering students in the Vietnamese context. Presentation at the 6th International Conference on Responding to Challenges of Teaching English for Communication, SEAMEO Regional Training Center, August 13-15, 2015, (pp. 5). Retrieved on $15^{\text {th }}$ June, 2020 from

https://www.researchgate.net/publication/298704361_Nee ds_analysis_of_English_for_mechanical_engineering_stu dents_in_the_Vietnamese_context

[19] Swartz, J., Pigg, S., Larsen, J., Gonzalez, J. H., De Haas, R., \& Wagner, E. (2018). Communication in the workplace: What can NC State students expect?" Report from the professional writing program. Department of English. North Carolina State University. In Last, S., Neveu, C., \& Smith, M. (2019). Technical writing essentials: Introduction to professional communication in the technical fields. University of Victoria. Retrieved on
$15^{\text {th }}$
June,
2020
from

https://pressbooks.bccampus.ca/technicalwriting/ 